\title{
Film Education in Cinemas - Determinants and Tendencies
}

The aim of the present article is to compare film education programmes in selected Polish cinemas, addressed at schools and based on the formula of the film academy (consisting of an introductory talk followed by a film screening). This model traces its roots back to film discussion clubs, although in the case of film academies the discussion usually does not follow the screening directly but takes place later in class.

In the article, I will discuss several such programmes offered by independent cinemas, including network cinemas, such as Filmoteka Szkolna. Nowe Horyzonty Edukacji Filmowej [Film Library. New Horizons of Film Education, NHEF] and KinoSzkoła [CinemaSchool], as well as the original project initiated by Amok cinema in Gliwice: Młodzieżowa Akademia Filmowa [Youth Film Academy] and Przedszkolna Akademia Filmowa "Pif PAF" ["Pif PAF" Kindergarten Film Academy] and finally, multiplexes, using the example of Multikino. The first part of the article discusses key elements of the Core Curriculum which provide reference for film education offers aimed at schools. The second part of the article is devoted to case studies. I discuss programmes of four film academies, focusing on their key assumptions, work methods and financing. In the summary, I compare and contrast these Polish film academies with European guidelines for film education.

The existing ministerial guidelines for film education in Poland are rooted in the tradition which originated before the World War II with writings of the philosopher Leopold Blaustein. Blaustein was one of the first Polish academics to explore the educational potential of films (Bobiński, 2011, pp. 73-75). His thought was continued in the works of Bolesław W. Lewicki, who graduated from John Casimir University in Lviv. Lewicki focused on both the artistic 
value of films and their potential to influence the spectators' moral attitudes. $\mathrm{He}$ argued that school should acquaint students with film masterpieces and foster their competence as viewers.

In the 1960s and 1970s, Lewicki, who was then the head of the Department of Film Studies in the Chair for Literary Theory at the University of Lodz, introduced elements of film education in the curriculum followed by future teachers of Polish language and literature. One of his students, Ewelina Nurczyńska-Fidelska, later became the leader of a team of teachers who championed film education in the school literature curriculum. As a result, film education in Poland became tied with literary education, and this approach is still reflected in the current Core Curriculum. Most importantly, however, owing to the work of Lodz teachers and academics, film is mainly treated anthropologically, as a text of culture with the socially important purpose of depicting the human condition (Bobiński, 2011, pp. 75-80; Nurczyńska-Fidelska, 1989; 1993).

Another important influence on Polish film education can be traced back to Herbert Read's theory of aesthetic education (Bobiński, 2011, p. 90), formulated in the 1940s and popularised in Poland by e.g. Bogdan Suchodolski (1967), Stefan Szuman (1969) and Irena Wojnar (1966, 1980). In film studies, the concept of aesthetic education found its champion in the educationalist Henryk Depta, who voiced the need to develop a comprehensive theory and methodology of using films in education. "It is my contention that film should be given a privileged position within aesthetic education. Why? The simplest answer is that since it is consistently present in our lives, it should similarly be present in our education" (Depta, 1975, p. 18). ${ }^{1}$ Depta distinguished between education on film (i.e. studying films) and education through film (i.e. learning through watching films); in his view, the latter was more important: "education on film must precede complex forms of education through film, but it is only because of its usefulness in this respect that film education is such a crucial component of learning" (Depta, 1975, pp. 22-26). In his writings, Depta described the educational benefits of exposure to various kinds of films (e.g. fairy tales, documentaries, scientific and genre cinema) and stressed the importance of proper pedagogical supervision in exploring the educational potential of films.

A belief in the importance of aesthetic education directs many contemporary didactic projects, including discussions and reflections around the Kids Film Festival, organised since 2014 in several Polish cities by the New Horizons Association. The $2^{\text {nd }}$ edition of the festival was accompanied by the "Black and White" project - a cycle of film screenings, exhibitions and debates on art addressed at teenagers and children, which provided material for a book of essays and interviews on art, beauty and cultural education (Kids Film Festival 2015).

\footnotetext{
1 In this book, Depta provides a bibliography of film education, recommending works by Read, Suchodolski, Szuman and Wojnar, as well as earlier writings on the educational merits of films by Blaustein. Depta also refers to the findings of e.g. Wojnar in another text, which proved seminal for film education in Poland: Film w życiu i wychowaniu mtodzieży (1983, s. 11).
} 


\section{Organisational Determinants of Film Education in Cinemas}

Film academies are usually scheduled during school hours, therefore students' participation in such activities must be justified by educational and social benefits for students and teachers alike. Most teachers and headmasters are willing to allow their students to participate whenever the topic of a film academy is related to the Core Curriculum (decreed by the Ministry of Education and regulating curricula for all levels from primary to upper-secondary education). The current Core Curriculum in Poland mentions films among the studied, analysed, interpreted and evaluated texts of culture. ${ }^{2}$ As far as early childhood education is concerned, films play a role in education through art. At stage I of school education (grades 1-3) elements of film studies are already included in arts education.

At stage II of education (grades 4-6 of primary education) and later in lowerand upper-secondary education, film education is mostly incorporated into Polish language classes. At grade 4-6 pupil should be acquainted with various texts of culture, including films, and have certain skills in analysing them. On this level, the analysis and interpretation of texts should consist of naming positive and negative values which they represent.

At stage III of education (lower secondary school - gimnazjum), one of the principal aims of education outlined in the Core Curriculum is to "develop a capacity for understanding, using and conscious transforming of various texts of culture, with the view of achieving personal goals, facilitating personal development and promoting active participation as a member of society". Another important aim is to prepare students for life in the information society. The scope of the material taught within Polish language classes comprises the analysis of various texts of popular culture (including films) focused on identifying literary and cultural tropes. The students are required to invent interpretation hypotheses and provide arguments in their defense. Guidelines for teachers specify that texts of culture discussed in class should be used for commenting on moral attitudes and values.

According to the Core Curriculum, upper-secondary students should perfect their ability to analyse and interpret texts, incorporating elements of comparative analysis. Special attention is paid to recognising recurring motifs and reading texts in context. All the same, the main focus is on literary texts and films can be referred to as allusions or contexts.

Apart from the Core Curriculum, another good reason for schools to participate in film academies is the correspondence of the event with the school's

\footnotetext{
All quotes from the Core Curriculum related to early childhood and primary school education from: The Minister of National Education Decree from 30 May 2014 amending the decree concerning the Core Curriculum for early childhood education and general education in all school types (Journal of Laws 2014, item 803), whereas all quotes referring to lower- and upper-secondary education are from: Minister of National Education Regulation of 27 August 2012 on the Core Curriculum for early childhood education and general education in all school types (Journal of Laws 2012, item 977).
} 
educational plan or prevention programmes. These educational guidelines determine the topics of film academies offered by cinemas. Below I will comment on several examples.

\section{Case Studies}

2.1 Filmoteka Szkolna. Nowe Horyzonty Edukacji Filmowej [Film Library. New Horizons of Film Education, NHEF]

The programme of Filmoteka Szkolna (initially called Nowe Horyzonty Edukacji Filmowej, NHEF) has been in operation since 2005. It is one of many initiatives coordinated by the Department of Education ${ }^{3}$ of the New Horizons Association, which was founded in 2003 in Warsaw. NHEF operates on a monthly basis from October to April, which amounts to 7 screenings per school year. In the first year of the project, the screenings were only organised in the Muranów Cinema in Warsaw; in 2015, however, a total number of 40 towns and cities participated, extending the programme to over 38,000 students and including over 180 different films. The speakers, who are recruited locally by the cinemas hosting the event, receive ready-made multimedia presentations from the New Horizons Association covering the topic of the meeting. The materials are prepared by professional teachers who cooperate with the association. Ticket prices are fixed by individual cinemas; they are nevertheless consistently lower than standard ticket prices. In NHEF, teachers are admitted free of charge; there are also free tickets for economically underprivileged students (the number of those is limited to three per group).

The project has the recommendations of the Polish Film Institute, the Minister of National Education and the Minister of Culture and National Heritage. In 2011, NHEF received the award of the Polish Film Institute in the category of "Young Audience Education"; in the same year, NHEF was merged with the Film Library - a film education programme conducted by the Polish Film Institute and focused on providing free copies of Polish films and film education didactic materials for all secondary education teachers in Poland. NHEF financing comes largely from the funds of the Polish Film Institute and the Ministry of Culture and National Heritage, while the cinemas hosting individual events rely on subsidies from Sieć Kin Lokalnych i Studyjnych's [the Network of Studio and Local Cinemas's] funds for education. Since 2010, NHEF's educational offer includes free didactic materials for teachers, i.e. class outlines based on topics connected with films and introductory talks presented during NHEF

\footnotetext{
Other projects organised by the association include: Kids Film Festival, Dzieciaki na horyzoncie [Kids on the Horizon] - film distribution for young audiences, aKino [aCinema] - film education addressed at schools and kindergartens, W-F Akademii Nowe Horyzonty [P.E. of the New Horizons Academy] - film workshops for teachers and educators, O filmie sie rozmawia [We Talk about Films] - a cycle of psychology workshops for children and their carers (in Warsaw and in Wroclaw), Wychowanie w kinie [Education in the Cinema] - meetings for teachers in Warsaw and Wroclaw, Film for Kids. Pro - a programme focused on developing film scripts for children.
} 
events, prepared by teachers, methodologists and film educators. This aspect of the programme is in constant development - at present, teachers and parents have access to psychological analyses of the films presented as part of the NHEF programme. Beginning from the school year 2016/2017, two more programmes have been added, both addressed at the early childhood education level: Chodze do kina [I go to the cinema] and Filmowe przygody [Film Adventures].

Therefore, there can be little doubt that NHEF offers an extensive programme, including several cycles for every educational level (although each cinema can individually decide to offer a smaller scale of events). The NHEF catalogue for the 2016/2017 school year consists of the following cycles (whose titles reflect their key educational aspects): grades 1-3 of primary education: "Film Classes (grade 1)", "Film Characters", "Film Journeys" and "Film Secrets"; grades 4-6 of primary education: "Film Classes (grade 4)", "Young People on Camera", "The Contemporary Cinema", "The World of Cinema"; lower-secondary education: "Film Classes 1\&2", "Young People on Camera", "Between Cultures", "The Contemporary World"; upper-secondary education: "Polish Cinema", "Multiculturalism in the Cinema", "Tough Subjects", "Film Analysis" and "Between Texts of Culture $(1 \& 2 \& 3)$ ". Films are mostly repeated from year to year; in the newest catalogue, which includes around 180 entries, only 26 films were listed as "new".

In comparison with previous NHEF editions, there is one important novelty: paths dedicated to specific educational levels, planned so as to introduce more diversity and enable each group to participate in the programme throughout their entire school education. Significantly, in the "Between Texts of Culture" cycle for upper-secondary students the material is organised according to literary periods, which reflects the Core Curriculum guidelines for Polish language classes and helps the students prepare for their matriculation examination.

The topics of NHEF sessions include contrastive analyses and discussions of motifs characteristic of literature and culture of a given period (e.g. tragedy Caesar Must Die [2012, dir. Paolo and Vittorio Taviani]; capitalism vs. moral values - The Promised Land [1975, dir. Andrzej Wajda]; evaluation of the Stalinist period - The Mother of Kings [1982, dir. Janusz Zaorski]. The cycle entitled "Polish Cinema" includes mostly contemporary films (e.g. Beats of Freedom [2011, dir. Leszek Gnoiński and Wojciech Słota]; Life Feels Good [2013, dir. Maciej Pieprzyca], with a smaller addition of "canonical" works (such as Man of Iron, 1981, dir. Andrzej Wajda).

The exception is the "Film Analysis" cycle, which is a strictly film-theory oriented programme addressed at upper-secondary students. There, discussions follow screenings and focus on narrative strategies, genre cinema and various formal aspects of films. The programme includes contemporary films, both foreign and Polish. There's also the study of film-oriented programmes for lower stages of education: "The secrets of films $1 \& 2 \& 3$ " for grades $1-3$, 
"The World of Films" for grades 4-6 and "Contemporary Cinema" for lowersecondary students.

The NHEF programme is mostly based on education through film, presenting material focused on situations and activities of everyday life (for the youngest audiences) or contemporary civilisation, political and religious problems (for older students). The "Lessons in the Cinema" cycle for stages I and II of primary education and lower-secondary education use films as a basis for teaching good behaviour and values, as well as creating relationships and cooperating with others. The cycle "Young People on Camera", available for stage II of primary education and lower-secondary education, proves especially successful in this respect. According to the findings of the research commissioned by the New Horizons Association and conducted on a group of 15 to 19-year-olds from the whole country, films play an important role in shaping young people's identity. According to their report,

$80 \%$ of teenagers declare that other people's stories help them better understand the world and themselves. $72 \%$ pay special attention to films presenting their peers' problems [...]. When asked to name the films that helped them understand their own identity, they tended to select stories of young people in more difficult circumstances than their own, as well as coming-ofage films (Oglądam, czuje, myśle - raport o mtodych w kinie, 2013).

NHEF film screenings focused on young people's stories include productions from many countries, although mostly European: Dutch, Norwegian, Danish, Swedish, British, and German. Polish productions are conspicuously under-represented, due to the fact that there are not many such films to choose from. In response, the New Horizons Association initiated the programme Film for Kids.Pro, whose aim is to promote scripts aimed at younger audiences. The cycle "Young People on Camera" is continued at the upper-secondary level with the cycle "Tough Subjects", which includes films focused on e.g. relationships between generations (Mommy, 2014 [dir. Xavier Dolan]), stereotypes concerning people with disabilities (Me Too, 2010 [dir. Antonio Naharro, Álvaro Pastor]), and issues of (im)maturity (Baby Blues [2013, dir. Katarzyna Rosłaniec]).

During meetings and discussion panels organised by NHEF in September 2015, many speakers pointed out that at present countries such as Norway, Denmark and the Netherlands are world leaders as far as films for children and teenagers are concerned; films produced in these countries were praised for their authenticity stemming from using familiar settings and naturalistic language. It should be noted, however, that although films selected by NHEF are poignant and interesting, there are certain cultural differences between the realities they represent and those known to Polish participants, which may have a negative impact on the viewers' ability to identify with the characters. 


\subsection{KinoSzkoła [CinemaSchool] Interdisciplinary Programme of Media Education}

KinoSzkoła [CinemaSchool] Interdisciplinary Programme of Media Education, operating since the 2011/2012 school year and hosted mostly by independent cinemas, is an interesting example of a multifaceted and network approach to film education. The programme was initiated by Joanna Zabłocka-Skorek (at that time a graduate of cultural studies at the University of Silesia specialising in film studies, presently a scholar with a doctoral degree in cultural studies) in cooperation with the actor and film specialist Marcin Skorek. The speakers and authors of educational materials for KinoSzkoła are film scholars, educators, teachers and filmmakers. KinoSzkoła received an award from the Polish Film Institute in the category of Young Audience Education for its undertakings in the year 2013 (it had been nominated twice previously). In the 2015/2016 school year, KinoSzkoła received the Filmoteka Narodowa (Polish Film Repository) Certificate, as well as recommendations from Centralny Gabinet Edukacji Filmowej [The Central Cabinet for Film Education] and the Centre for Education Development.

Until the end of the 2014/2015 school year, KinoSzkoła was a privately owned company. In September 2015, it was transformed into KinoSzkoła Fundacja Rozwoju Kompetencji Medialnych i Społecznych [KinoSzkoła Foundation for the Development of Media and Social Competences] and this new body became the official producer of its educational programme.

Thanks to the change of its legal status, KinoSzkoła became eligible for public funding. ${ }^{4}$ Before that, the company financed itself through charging cinemas for the services it provided: an educational programme, as well as introductory talk and access to didactic materials. Film screening licence fees are covered by the cinemas, which can receive special subsidies for educational programmes from the Network of Studio and Local Cinemas. For participants, the cost is similar to that of participating in other programmes discussed in this article. Ticket prices are fixed by individual cinemas, however, the organisers suggest the following: a student pass for 5 screenings: PLN 35; 7 screenings: PLN 45; 9 screenings: PLN 60.

KinoSzkoła educational programme has several components. The organisers are chiefly concerned with the aspect of social prevention and prioritise it when planning screenings, introductory talks and didactic materials titled Film Signposts (I will discuss these in more detail later in the article). Among other educational cycles are: "Film Alphabet", a series of 3D screenings organised bimonthly and devoted to the study of films, and "KinoPrzedszkole" [CinemaKindergarten],

4 In the first session of the Polish Film Institute contest, in the category Operational Programme: Education and Popularisation of Film Culture, $1^{\text {st }}$ Priority: Film Education and Professional Training, the foundation was granted a sum of PLN 100,000. The yearly cost of the entire programme was estimated at PLN 904,718 zł, and the foundation filed for support worth PLN 448,118 zł (Pisf.pl, Sesja 1/2016). 
addressed at the youngest audiences and involving screenings of short films with introductions and breaks for educational tasks. In addition to this, KinoSzkoła offers media workshops addressed at students at all levels of education; from stage II of primary education (grades 4-6) onwards teachers can choose between two different cycles. Additionally, during Lent, KinoSzkoła organises "A Spiritual Film Retreat". The foundation offers workshops for teachers and, in addition, since the 2015/2015 school year, workshops for parents and screenings for senior audiences.

From the outset, KinoSzkoła's offer is directed primarily at independent cinemas in towns under 100,000 inhabitants (Skorek, 2015), as its chief aim is to provide access to film education for students from smaller administrative units. At present, it has a national scope. In the 2015/2016 school year, the $5^{\text {th }}$ edition of KinoSzkoła has taken place in 52 venues (cinemas and community culture centres), in 11 voivodeships. One multiplex cinema has also joined in: Planet Cinema in Oświęcim. In the school year 2014/2015, educational screenings were attended by 115,000 young viewers; the programme encompassed a total of 700 screenings, over 150 events for early childhood care pupils and over 170 workshops. According to the latest data from May 2016, the current school year 2015/2016, although still in progress, has already attracted 159,000 viewers, who participated in 1041 screenings; additionally, 354 workshops and 354 events for early childhood care pupils have taken place. 5

The assumptions of the social prevention cycle "Film Signposts" stem directly from its author's academic and educational experience. In 2015, Zabłocka-Skorek completed her $\mathrm{PhD}$ degree at the Jagiellonian University in Cracow, defending her thesis on Axiological Aspects of Audiovisual Education in the Context of Dominant Receiving Practices of Polish Lower- and Upper-Secondary Students (Zabłocka-Skorek). In her dissertation, based on questionnaires filled in by students, Zabłocka-Skorek analyses dominant moral tendencies among young people and subsequently proves that film is a very efficient tool for shaping young viewers' moral attitudes. Zabłocka-Skorek's diagnoses and recommendations are indebted to the works of Depta (mentioned earlier in the present article) as well as other influential scholars active in the 1960s and 1970s (Joanna Koblewska-Wróblowa, Stefan Morawski). She also refers to the more contemporary findings of Witold Adamczyk (2012, 2005), regarding psychological aspects of young people's perception of film characters, as well as the cognitive studies of Bogusław Skowronek (2007).

An enthusiast of education through film, Zabłocka-Skorek argues that "the main objective of KinoSzkoła [...] is to assist teachers in their educational work, hence the social prevention cycle "Film Signposts» [...] is addressed especially at school teachers and educationalists [...]. The topics of educational talks and corresponding films were selected on the basis of an analysis of the Core Curriculum for the following school subjects: ethics, social studies, family life education,

\footnotetext{
5 Data of the organisers.
} 
Polish language, cultural studies and history, as well as particular schools' social prevention programmes and educational plans" (Zabłocka-Skorek, 2015, p. 113). Comparing the topics offered for all educational stages, it is possible to identify certain recurring themes such as axiology, the body, human relationships, responsibility, family life, tradition, disability, multiculturalism and peer violence in the real and digital world.

The films selected for the project are almost exclusively recent productions (from the last few years). They represent mostly European cinema (including Polish cinema); many of them are produced by Scandinavian countries and distributed by the Gutek Film company; often the same films are selected by the New Horizons Association for their programmes. Some films in this cycle belong to the American mainstream, e. g. Swing Vote (2007, dir. Joshua Michael Stern), Robosapiens (2013, dir. Sean MacNamara), Bling Ring (2013, dir. Sofia Coppola), or to the international canon, e.g. Hayao Miyazaki's animations. In Zabłocka-Skorek's view, "only through keeping our selection up to date and adding more and more recent films can we get across to the younger audiences. I agree with Depta, who claimed that it is impossible to create a fixed canon of classical films for children and teenagers" (Zabłocka-Skorek, 2015, p. 125).

She also argues against criticism of entertainment-oriented popular cinema, as she believes that such films can win the hearts of the youngest viewers, opening them to the enjoyment that comes from watching films. Subsequently, children can be gradually taught to develop faculties necessary in watching more demanding, canonical works (Zabłocka-Skorek, 2015, s. 125). In the school year 2015/2016, the programme addressed at upper-secondary students included a cycle of mini-lectures on the world and Polish film canon (the talks covered e.g. films by Andrzej Wajda, Krzysztof Zanussi, Federico Fellini and Ingmar Bergman), motivated by the Core Curriculum which only demands a very general scope of knowledge about outstanding cinema artists and film masterpieces at this level of education.

Analysing the programmes of all five editions of KinoSzkoła, it can be noted that certain titles incorporated in the $1^{\text {st }}$ and $2^{\text {nd }}$ editions recur in editions 4,5 and 6 . This is due to the fact that each educational stage lasts three years and after that period new students join in, which means that certain films - viewed by the organisers as especially important - can be incorporated again, although usually the topic of the introductory talk is changed. The film Akeelah (2006, dir. Doug Atchison), selected for lower-secondary students, is a case in point. In the school year 2011/2012, it was accompanied by a talk entitled Interior signposts, or values. Studying pays off!, while in 2014/2015 the talk was titled Nerds and the others: on acceptance and peer pressure. Another good example (for lower-secondary level) is Juno (2007, dir. Jason Reitman). Initially, the talk was titled Teenage anxieties: Adulthood versus maturity (2011/2012); subsequently, it became High-risk behaviour among teenagers: Early sexual initiation (2014/2015). In some cases, the talks remained unchanged, e.g. the film In a Better World (2010, dir. Susanne Bier) 
was twice preceded by the talk Sources of violence (2011/2012 and 2014/2015) and Piggies (2009, dir. Robert Gliński) was twice paired with the talk On dignity and respect for the body (2011/2012, 2014/2015).

Each screening within the "Film Signposts" cycle is preceded by a half-hour introductory talk carried out by film scholars, educationalists, psychologists and other specialists on youth education. As Zabłocka-Skorek points out, the chief objective of the talk is to establish a connection with the audience and initiate interaction in order to achieve specific educational or therapeutic effects. All didactic materials - presentations for the speakers and class outlines for teachers - are prepared beforehand by specialists in film education (some of them are the speakers themselves). Thanks to cooperation with the New Horizons Association, some films and materials used by NHEF are offered to KinoSzkoła; however, in some cases, Zabłocka-Skorek decides to present them in different educational contexts.

In 2015, the co-author of the programme Marcin Skorek firmly declared that the introductory talks are not concerned with any formal qualities of films (Skorek, 2015) but they fulfil educational aims instead, stimulating young viewers to reflect on the proposed topics and participate in discussions on selected axiological issues. In contrast, the 3D cycle is film theory oriented. This particular cycle is not offered to all age groups: in the school year 2013/2014 it was directed at primary and lower-secondary students, in 2014/2015 it was offered exclusively to stage I and II of primary education and in 2015/2016 - only to grades $1-3$ of primary school (stage I). It should be noted, however, that certain aspects of film theory are incorporated into the rich offer of workshops focused on developing media, digital and information competences (Budzisz, 2014). Their topics include film and other art forms as well as new media or elements of communication and literary theory. This scope of topics allows teachers to meet the requirements imposed by the Core Curriculum as far as media education and film education are concerned. This aspect of KinoSzkoła, however, falls beyond the scope of the present article.

\subsection{Amok Cinema in Gliwice - An Original Local Programme}

Amok cinema in Gliwice has been offering two film education programmes: Młodzieżowa Akademia Filmowa - MAF [Youth Film Academy - MAF] and Przedszkolna Akademia Filmowa "Pif PAF" ["Pif PAF" Kindergarten Film Academy] ever since 1992. In 2004, the cinema joined the Network of Studio and Local Cinemas and Europa-Cinemas network; in 2011, it also joined the Polish Digital Cinema Network. At present, it constitutes a part of a community cultural institution, Gliwicki Teatr Muzyczny [Music Theatre in Gliwice]. In 2013, Amok cinema received the distinction of the Polish Film Institute in the Best Cinema category. The Młodzieżowa Akademia Filmowa programme has three times been distinguished with a Filmoteka Narodowa [Polish Film Repository] certificate for the outstanding quality of its educational events (school years 2014/2015, 2015/2016 and 2016/2017). 
The MAF programme includes 10 sessions per school year for each educational level. Among the participants are students from Gliwice and the neighbouring towns of Pyskowice, Toszek, Wielowieś, Knurów, Zabrze and Tarnowskie Góry. Every session consists of a film screening preceded by an introductory talk. Additionally, teachers receive didactic materials prepared by the speaker, such as class outlines or ideas for educational projects corresponding with the topic of a given event. The programme is presented by two specialists: Urszula Biel, PhD (the manager) and Agnieszka Piotrowska-Prażuch, MA (assistant manager), with the help of the speakers.

The programme is always prepared in advance - all screenings for the forthcoming school year are planned in June. The organisers only select films that they have already seen, which means that they do not include any premieres. In accordance with the cinema's profile (its membership in the Network of Studio and Local Cinemas and Europa-Cinemas network), the majority of films incorporated in the programme are European productions, including Polish. ${ }^{6}$ Occasionally, some older, canonical titles are added, e.g. Cinema Paradiso (1988, dir. Giuseppe Tornatore), which was presented to lower-secondary students in the school year 2015/2016 within the cycle "Cinema as a window to the world". The decisions to include older films are usually prompted by digital reconstructions and re-premieres.

The organisers act with the view of accomplishing several aims. First of all, the programme is to educate, by shaping the viewers moral attitudes, as well as extend their cultural competence. The educational merit of MAF is primarily concerned with culture. The introductory talks tackle subjects such as good manners (Gentlebear, that is a well-mannered bear-Paddington [2014, dir. Paul King], grades 1-3 of primary education, the 2015/2016 school year); multiculturalism (Different cultures, mutual language! The thing about multiculturalism - MGP Missionen [2014, dir. Martin Miehe-Renard], grades 4-6 of primary education, the 2015/2016 school year; Man in the melting pot-Qu'est-ce qu'on a fait au bon dieu? [2014, dir. Philippe de Chauveron], lower-secondary level, the 2015/2016 school year); religion [Islamic culture - Wadjda (2012, dir. Haifaa AlMansour), lower-secondary level, the 2015/2016 school year; Welcome to Ireland: legends, culture, history - A Shine of Rainbows (2009, dir. Vic Sarin), grades 4-6 of primary school, the 2015/2016 school year]; politics and international relations (Letters from Russia - Leviathan [2014, dir. Andriej Zwiagincew], uppersecondary level, the 2015/2016 school year; Middle East, Distant Peace - Omar [2013, dir. Hany Abu-Assad], upper-secondary level, the 2015/2016 school year); psychology (On the path to adulthood - Boy [2010, dir. Taika Waititi], lowersecondary level, the 2015/2016 school year; How to talk about difficult matters? - Songs of the Sea [2014, dir. Tomm Moore], grades 1-3 of primary education, the 2015/2016 school year).

${ }^{6}$ In the cinema's daily repertoire, at least $30 \%$ of films must be European productions and at least $20 \%$ must be Polish. 
Topics specifically concerned with film theory are rare. In the school year 2015/2016, there was one session on animation for grades 1-3 of primary education (A sheep made of plasticine? Animation techniques - Shaun the Sheep [2015, dir. Mark Burton, Richard Starzak]), one on film adaptation for lower-secondary students (From page to screen - Little Prince [2015, dir. Mark Osborne]) and Cinema as a window to the world (mentioned above). It should be noted that initially, the MAF programme was more film theory oriented, however, with time, the organisers decided to broaden the scope of subjects and shift the emphasis from education on film to education through film.

The topics and films on offer are supposed to correspond with the Core Curriculum. Teachers can make sure that this is the case by consulting the instructions attached to the programme. Every film description is accompanied by the topic of the introductory talk (T), a list of key motifs $(\mathrm{M})$ and school subjects within which a given film can be discussed (S). ${ }^{7}$ For example, the film Avengers: Age of Ultron ([2015, dir. Joss Whedon] lower-secondary level, the 2015/2016 school year) is accompanied by a talk titled Contemporary versions of fairy tales; the key motifs include: science-fiction, mythology, fairy tales, magic, superheroes; and finally, the school subjects that correspond with the issues tackled by the film are Polish language and knowledge about society.

Another objective of MAF is to shape the young audience's tastes through acquainting them with cinematic works of high artistic value as well as cinema d'auteur (with a focus on original narrative techniques and character development different from that of an American blockbuster). Still, every year the programme incorporates some box office hits. In 2015/2016, these were: Avengers: Age of Ultron (lower-secondary level), Ex Machina ([2015, dir. Alex Garland] upper-secondary level), Cinderella ([2015, dir. Kenneth Branagh] grades 1-3 of primary school). The organisers declare that their aim is to select good films that provide food for thought, films that have won prizes at European festivals, perhaps occasionally demanding, but representing the highest achievements in filmmaking.

Every year, the talks within each cycle are delivered by a different speaker, selected on the basis of their knowledge of the subject as well as their experience in education. As a result, MAF cooperates not only with film scholars but also with historians, employees of the Institute of National Remembrance, sociologists, psychologists, literary scholars and NGO representatives. Some topics are developed in cooperation with the speakers. Apart from delivering the talk, their tasks include preparing didactic materials for teachers to use in the classroom after the screening. Activities suggested in the materials do not have to reflect the topic directly; they can broaden the scope of discussion or introduce new problems connected with the film.

This part of the description is included in printed programme leaflets. On the cinema's website, follow the link from a film title. 
The costs of participation in MAF in the school year 2015/2016 were as follows: one session - PLN 12, a pass for 3-5 sessions - PLN 10 per session, a pass for 6-10 sessions - PLN 8 per session; with ticket prices for 3D screenings ranging from PLN 10 to PLN 18 depending on the discount, day and hour. MAF is not a profitoriented initiative; nevertheless, with a participation rate reaching 15,000 students in $2015 / 2016^{8}$ it has become a moderate commercial success. The costs (licence fees, speakers' wages) are covered from ticket sale income as well as funding from the Network of Studio and Local Cinemas that administrates funds granted by the Polish Film Institute. Amok cinema, as a part of a community cultural institution, also receives a subsidy from the local administration.

\subsection{Multikino - a Film Academy in a Multiplex ${ }^{9}$}

To analyse the case of a film academy conducted in a multi-screen cinema network I will use the example of Multikino. In operation since 1998, Multikino is the second biggest multiplex cinema network in Poland (with 33 cinemas registered in 2016). Akademia Filmowa Multikina [Multikino Film Academy, AFM] offers four-session film education cycles lasting one semester. ${ }^{10}$ The programme is addressed at students at all educational levels as well as children in early childhood education (the cycle titled "My First Visit to the Cinema"). The academy is organised at all of the network's cinemas. In some cases, schools buy passes for the entire school year in advance, while in others groups only participate in selected events. Every year, nearly 100,000 students in the whole country take part in events organised by AFM. As in the case of independent cinemas, tickets for MFA screenings are cheaper. The organisers declare that their chief objective is to educate viewers and promote the Multikino brand among students. That is why they seek to cover their costs (licence fees, speakers' wages) not from ticket sales but from other profits and donations. ${ }^{11}$

The programme of the academy is the same for all Multikino cinemas. It is prepared by the company Pracownia Ferment Kolektiv from Poznań, which was established in 2007 and since then it has been dealing with film education and organisation of artistic events. What is important, even though Multikino is an international network, its film education programmes are planned locally (on a national level). Multikino's owner, Vue Entertainment Ltd, gives carte blanche to national networks and does not provide any international guidelines in this respect. In Poland, the authors of film academy programmes are: Radosław Tomasik, Paulina Łosińska-Tomasik and Agnieszka Powierska - all of whom are film studies graduates and alumni of the Adam Mickiewicz University in

8 Data of the cinema management.

9 I received the data concerning AFM directly from Radosław Tomasik (Multikino Sales and Marketing Department) who is also one of the authors of the AFM programme, acting on behalf of the company Pracownia Ferment Kolektiv.

10 The programme for the second semester of the year 2015/2016 is available online at: https://multikino. pl/repozytorium/szkoly/AKADEMIA2016_final.pdf.

11 The Multkino network does not reveal any precise financial data. 
Poznań. In their didactic and cultural work, they cooperate with Ale Kino! International Young Audience Film Festival in Poznań, Transatlantyk Festival in Lodz and Suspense Film Festival in Kołobrzeg. Pracownia Ferment Kolektiv provides five-minute educational films which are presented as part of introductory talks and include additional contexts from art, cinema and literature, corresponding with a given topic. This method not only makes the talk more diverse, but also answers the demands of the Core Curriculum in terms of fostering contrastive analytic skills and recognising key motifs in cultural history.

As far as class outlines are concerned, Pracownia Ferment Kolektiv cooperates with teachers, methodologists and academics. Individual speakers are selected locally by each cinema. Like in other cases discussed above, MFA speakers are not only film scholars and critics, but also policemen, sportsmen, soldiers, NGO workers, zoologists, physicists, astronomers, addiction prevention specialists and other experts.

Similarly to KinoSzkoła, NHEF and Amok cinema, MFA bases its programme on European cinema, which may seem rather surprising, given that most films in the network's repertoire are Hollywood blockbusters. Still, in the second semester of the school year 2015/2016, MFA included many titles that have also been used by other programmes discussed above (in the same year or earlier), e.g. for grades 4-6 of primary education Songs of the Sea, also presented in Amok cinema, and Karsten og Petra på Vinterferie [2014, dir. Arne Lindtner Naess], also presented by NHEF and KinoSzkoła; for lower-secondary students: (Whale Rider [2002, dir. Niki Caro], also in NHEF and "KinoSzkoła") and (The Rocket [2013, dir. Kim Mordaunt], also in KinoSzkoła). MFA organisers do their best to select films that on the one hand are of outstanding artistic quality, but on the other hand are not too demanding for the audience, so as to make sure that young viewers can profit from the experience. This approach seems to be shared by all the academies discussed here.

While in the case of MFA the programme for primary and lower-secondary schools is arranged monthly, the offer for upper-secondary students is always marked as "by individual appointment". Teachers can also order special thematic sessions for lower-secondary students, which are co-organised with the police. There are two topics available: Designer drugs: prevention and Haters out, or from netiquette to cybercrime: Violence in and outside the Internet, and within each topic there are three different films to choose from. These topics are directly linked with developing media, digital and information competences (discussed above in the context of the KinoSzkoła programme) outlined by the Modern Poland Foundation and mentioned in the Core Curriculum. According to the organisers, these topics are popular with teachers. Another option to extend the MFA offer are screenings of films found in the current Multikino repertoire - the MFA catalogue lists these with corresponding dates. These films are not, however, accompanied by any additional educational components (introductory talks, materials for teachers). 
The topics selected for MFA events correspond with broadly defined cultural issues, such as values, traditions, beliefs and customs, social and family relations or contemporary cultural practices (e.g. sport, superheroes, compartmentalising the world into "us" and "them"). The organisers declare that

at the earliest stages of education, [the Academy - author's note] provides a perfect alternative to integrated cultural activities. At higher levels, it supplies additional information that complements the skills and knowledge taught at school during Polish language, cultural studies and advisory classes. For upper-secondary students, MFA sessions provide an opportunity to broaden their knowledge before the matriculation exam (Akademia Filmowa 2014-2015. II semestr, p. 20).

In the current MFA repertoire, however, many films touch upon such civilisational issues as the contemporary model of master-student relationship (in relation to Carte Blanche [2015] by Jacek Lusiński), the personal and social context of Zbigniew Religa's biography as a hero in Communist Poland [Gods, 2015, dir. Łukasz Palkowski] or the position of women and relationships in Muslim Turkey [Mustang, 2015, dir. Deniz Gamze Ergüven]. A typically matriculation exam-oriented session was devoted to the discussion of literary motifs and their contemporary contexts [Macbeth, 2015, dir. Justin Kurzel]. All the sessions were accompanied by short educational films (mentioned above), stressing how the discussed cinematic works correspond with the history of culture and civilisation.

It should also be noted that each topic (from the very first educational stage) is supplemented by elements of film theory, selected so as to match a given film. It may be said then that the organisers try to coordinate elements of education on film with education through film, answering Depta's postulate (quoted earlier in the article) that education on film is only fully justified when it facilitates achieving general educational results.

\section{Conclusion}

There is one important premise that needs to be formulated before the final conclusion is made: the analysis presented in this article is based mainly on event programmes and discussions with the organisers of the film academies in question, as well as the author's own experience of cooperation with MFA in Gliwice, NHEF and KinoSzkoła, which means that the present research is founded mostly on declared programmes. There still remains further need to analyse the implementation of each programme through regular observation over a long period of time as well as systemic analysis of didactic materials offered, complemented by questionnaires for teachers in order to find out how many of them actually put the academies' class outlines to use and how they evaluate these materials. 
Looking at the discussed film academies from a more general perspective, it may be suggested that all of them fall within the so-called dispersed model of film education, in which elements of film education are incorporated into the syllabuses of multiple school subjects (Bobiński, 2011, p. 63; Koblewska, 1976). It can be noticed that all three film academies tend to prioritise education through film over education on film (which dominated in the past, when similar initiatives tended to focus on transmitting knowledge with regard to film history, production and theory ${ }^{12}$ ). This tendency seems to have developed simultaneously with Polish studies and practices within the field of film therapy (Warmuz-Warmuzińska, 2013, 2015; Kozubek, 2016; Kinoterapia.pl). The "cultural" profile of most film academies is clearly influenced by current European tendencies postulating the broadest possible scope of influence of film works on young people's education.

According to the document titled A Framework for Film Education, produced in the years 2014/2015 by a group of 25 experts (experienced film educators) from 20 countries, the key dimensions of film education should be: creative dimension, critical dimension and cultural dimension (A Framework for Film Education, p. 7). According to the main aims for film education outlined in the document, the participants should learn to "understand what is specific and distinctive about film", to "know that film is both collectively and collaboratively, as well as personally and individually, produced and consumed", to "personally engage with film from a critical, aesthetic, emotional, cultural and creative perspective" and to "develop an awareness of the social and historical context to film" (A Framework for Film Education, p. 3). In film education based on watching films in a cinema environment, learning about film history and discussions on national and world cultures, the participants are supposed to develop mental attitudes that would assist lifelong learning (i.e. curiosity, empathy, aspiration, tolerance, enjoyment), experience an enhancement of their personal development as well as a rise in civic responsibility, and finally increase their employability (A Framework for Film Education, p. 26). Polish film academies seem to be headed towards similar objectives, as their programmes are invariably focused on issues connected with contemporary culture and civilisation in all their aspects.

Even though every programme introduces some elements of film theory, emphasis is placed on educational values of films (the most balanced programme in this respect is Multikino's MAF). This tendency may be alarming in the sense that it is difficult to extract meanings from a cinematic work without referring to various formal elements and understanding how things such as editing, frame composition or lighting determine the viewer's experience. Among the key areas of film education, the authors of $A$ Framework for Film Education list specific qualities of films - a subject that seems to be rather neglected by Polish film academies. Although the Core Curriculum incorporates elements of film theory

${ }^{12}$ I have reached this conclusion on the basis of the analysis of former school academy programmes as well as discussions with several authors of such programmes. 
into the scope of Polish language and arts (later also cultural studies) from the earliest stages of education, this issue is not universally addressed.

The sheer existence of separate film academy programmes in cinemas stems from the fact that in schools films are often treated only as additional material, perceived as more easily absorbed than literary works - and as such, not requiring an equal amount of reflection or any specific competence on the part of the viewer (Litorowicz, Majewski, 2011). ${ }^{13}$ Other impediments to film education in schools are the lack of time or equipment, as well as insufficient free legal access to films (in this respect, however, the situation seems to be improving thanks to various funding schemes and the creation of film sets for classroom purposes). For all these reasons, film analysis in schools often consists of discussing merely the content of films, without reflecting on formal devices employed by the medium. ${ }^{14}$

Transferring film education from schools to cinemas can be interpreted as a consequence of teachers' lack of competence in covering this subject. That is why there is a wide offer for teachers who want to broaden their knowledge on the subject, e.g. workshops organised by Filmoteka Szkolna [Film Library] in cooperation with the Centre for Citizenship Education or various initiatives conducted by regional teacher training centres. Nevertheless, there is still no unified list of all such workshops and training sessions available. Another aspect mentioned by teachers in the Filmoteka Szkolna report is the shortage of practical school workshops (even in artistically-oriented classes) focused on filmmaking, which could substantially increase learners' analytic and interpretative skills through individual experience of the filmmaking process.

In A Framework for Film Education, learners' own attempts at filmmaking are discussed as crucial experience assisting the development of analytical and critical thinking. Interestingly, this aspect is prioritised in Denmark, where there are special young filmmaker programmes implemented in schools with the view of enabling students to gain practical experience in this field (Wad, 2015). ${ }^{15}$

It cannot be expected that such programmes conducted outside school (although during school time) can fulfil all the requirements posed by the Core Curriculum and international educational tendencies. The three film academies discussed in this article are rather similar and their biggest value seems to lie in providing students (and teachers) with opportunities to get acquainted with

13 The research was conducted on a group of 30 teachers, which can hardly be treated as representative. Nevertheless, my experience suggests that their answers correspond to what most teachers express at conferences and during workshops on film education.

${ }^{14}$ It is no coincidence that in my professional experience, whenever I conduct workshops for teachers or teach sample classes in lower- and upper-secondary schools, I am asked to cover issues such as: "the language of films", "film analysis", "film modes of expression", "film genres" etc.

15 Video recording of the presentation with English subtitles available at: https://www.youtube. com/watch?v=WPP3jvDa7-o\&list=PL8Cphkmgof19-IZDmmbjXgH9wm4SQhv9_\&index=3. PowerPoint presentation in English available at: http://come.uw.edu.pl/peam/program2015.php. 
important (in terms of subject) and good (in terms of artistic quality) European cinematic works, which are not necessarily the obvious choices of young people in their spare time. Low ticket prices and availability of events organised in cities and towns alike contribute to the growing popularity of film academies. It can be hoped that the organisers' clear intention to educate through film will produce the results outlined in A Framework for Film Education, and the future editions of film academies will successfully combine elements of educational and film theory-oriented approaches, confronting young audiences with contemporary films that best appeal to their sensibility.

\section{Bibliography:}

A Framework for Film Education (2015), http://www.koalicjafilmowa.pl/admin/reports/\%20bfia-framework-for-film-education-brochure-2015-06-12.pdf (access: 17.06.2016).

Adamczyk, W. (2012). Bohater filmowy w percepcji mtodzieży. Film w procesie ksztattowania standardów osobistych uczniów szkolnych $i$ studentów oraz konceptualizacji tworzonego przez nich wizerunku rzeczywistości. Bielsko-Biała: Wydawnictwo Naukowe Akademii TechnicznoHumanistycznej.

Adamczyk, W. (2005). Psychologiczny model widza kinowego. Przyczyny preferencji filmów produkcji amerykańskiej oraz ich skutki wychowawcze wśród mtodzieży szkolnej i akademickiej. Bielsko-Biała: Wydawnictwo Naukowe Akademii Techniczno-Humanistycznej.

Akademia Filmowa 2014-2015. II semestr. https://multikino.pl/repozytorium/szkoly/ AKADEMIA2016_final.pdf (access: 16.06.2016).

Bobiński, W. (2011). Teksty w lustrze ekranu. Okotofilmowa strategia ksztatcenia literackokulturowego. Kraków: Towarzystwo Autorów i Wydawców Prac Naukowych Universitas.

Budzisz, W. (ed.) (2014). Katalog kompetencji medialnych, informacyjnych i cyfrowych, http://edukacjamedialna.edu.pl/media/chunks/attachment/Katalog_kompetencji_ medialnych_2014_EudBrrI.pdf (access: 17.06.2016).

Depta, H. (1975). Film i wychowanie. Warszawa: Wydawnictwa Szkolne i Pedagogiczne.

Depta, H. (1983). Film w życiu i wychowaniu mtodzieży. Warszawa: Wydawnictwa Uniwersytetu Warszawskiego.

Journal of Laws of 2012, item 977. Rozporzadzenie Ministra Edukacji Narodowej z dnia 27 sierpnia 2012 w sprawie podstawy programowej wychowania przedszkolnego oraz ksztatcenia ogólnego w poszczególnych typach szkót [Decree of the Minister of National Education from 27 August 2012 on the Core Curriculum for early childhood education and care and general education in all school types]. https://www.librus.pl/wp-content/uploads/2013/05/ Rozporzadzenie-w-sprawie-podstawy-programowej-wychowania-przedszkolnego-orazksztalcenia-ogolnego.pdf (access: 17.06.2016).

Journal of Laws of 2014, item 803. Rozporzadzenie Ministra Edukacji Narodowej z dnia 30 maja 2014 zmieniajacym rozporządzenie w sprawie podstawy programowej wychowania przedszkolnego oraz ksztatcenia ogólnego w poszczególnych typach szkót [Decree of the Minister of National Education from 30 May 2014 amending the regulation on the Core Curriculum for early childhood education and general education in all school types]. https://www.librus. pl/wp-content/uploads/2014/10/D20140803.pdf (access: 17.06.2016).

Ferment Kolektiv. http://www.ferment.com.pl/.

Festiwal Filmowy Kino Dzieci 2015. https://issuu.com/nowehoryzonty/docs/kd-katalogwww?e=5903820/30076555 (access: 17.06.2016). 
KinoSzkoła. http://kinoszkola.pl/.

Kinoterapia.pl. http://www.kinoterapia.pl.

Koblewska, J. (1976). Wspótczesne modele edukacji filmowej na świecie, [in:] J. Masłowska (ed.). Modele edukacji filmowej. Warszawa: Centralny Ośrodek Metodyki Upowszechniania Kultury.

Kozubek, M. (2016). Filmoterapia. Teoria i praktyka. Gdańsk: Słowo/obraz terytoria.

Litorowicz, A., Majewski, P. Raport: Edukacja filmowa w polskiej szkole na podstawie opinii nauczycieli uczestniczacych w warsztatach Filmoteki Szkolnej, Warszawa 11 September 2011. http://www.koalicjafilmowa.pl/admin/reports/Raport_EDUKACJA_FILMOWA_W_ POLSKIEJ_SZKOLE.pdf (access: 17.06.2016).

Łapińska, J. (2015). Film education from the film festival organisers' point of view. http://come. uw.edu.pl/peam/program2015.php (access: 17.06.2016).

Nowe Horyzonty Edukacji Filmowej. http://www.nhef.pl/.

Nurczyńska-Fidelska, E. (1989). Edukacja filmowa na tle kultury literackiej. Łódź: Wydawnictwo Uniwersytetu Łódzkiego.

Nurczyńska-Fidelska, E. (1993) (ed.). Film w szkolnej edukacji humanistycznej. WarszawaŁódź: Wydawnictwo Naukowe PWN.

Nurczyńska-Fidelska, E. (1966). Perspektywy wychowawcze sztuki. Warszawa: Nasza Księgarnia.

Ogladam, czuje, myśle - raport o mtodych w kinie (2013). http://www.koalicjafilmowa.pl/ admin/reports/NHEF_materialy_prasowe.pdf (access: 17.06.2016).

Pisf.pl, Sesja 1/2016. https://www.pisf.pl/dotacje/dofinansowane-projekty/2016/po-edukacjai-upowszechnianie-kultury-filmowej/priorytet-1-sesja-1-2016 (access: 17.06.2016).

Raport: Edukacja filmowa w polskiej szkole na podstawie opinii nauczycieli uczestniczacych w warsztatach „Filmoteki Szkolnej” (2011). Warszawa. http://www.koalicjafilmowa.pl/ admin/reports/Raport_EDUKACJA_FILMOWA_W_POLSKIEJ_SZKOLE.pdf (access: 17.06.2016)

Read, H. (1958). Education through Art. London: Faber and Faber.

Skorek, M. (2015). Interdisciplinary Media Education Programme KinoSzkota 2013/2014. Film and Media Education in Poland and the World: Systemic Solutions and Case Studies Conference. Warszawa: University of Warsaw, 6-7 May. http://come.uw.edu.pl/peam/ program2015.php (access: 17.06.2016).

Skowronek, B. (2007). Konceptualizacje filmu i jego ogladania w języku mtodzieży. Studium kognitywno-kulturowe. Kraków: Wydawnictwo Naukowe Akademii Pedagogicznej.

Suchodolski, B. (1967). Podstawy wychowania socjalistycznego. Warszawa: Książka i Wiedza.

Szuman, S. (1969). O sztuce i wychowaniu estetycznym. Warszawa: Wydawnictwa Szkolne i Pedagogiczne.

Wad, S. (2015). Station Next, Film and Media Education in Poland and the World: Systemic Solutions and Case Studies Conference. Warszawa: University of Warsaw, 6-7 May. http:// come.uw.edu.pl/peam/program2015.php (access: 17.06.2016).

Warmuz-Warmuzińska, E. (2015). Filmoterapia: scenariusze zajęć w edukacji filmowej dzieci $i$ dorostych. Warszawa: Difin.

Warmuz-Warmuzińska, E. (2013). Filmoterapia w edukacji i terapii dzieci i mtodzieży szkolnej oraz dorostych. Warszawa: Difin.

Wojnar, I. (1966). Perspektywy wychowawcze sztuki. Warszawa: Nasza Księgarnia.

Wojnar, I. (1984). Teoria wychowania estetycznego. Warszawa: Państwowe Wydawnictwo Naukowe. 
Zabłocka-Skorek, J. http://www.wzks.uj.edu.pl/documents/41653/78870620/streszczZablocka-Skoerk-pl.pdf (access: 17.06.2016).

Zabłocka-Skorek, J. (2015). Edukacja filmowa w praktyce. Dobór filmów w Interdyscyplinarnym Programie Edukacji Medialnej "KinoSzkota" w kontekście recepcji filmu przez mtodego widza, [in:] J. H. Budzik, I. Copik (eds.). Edukacja przez stowo-obraz-dżwięk. Katowice: Wydawnictwo Uniwersytetu Śląskiego.

\section{Summary}

The article is an attempt at critical analysis of selected film education programmes addressed at school students by independent and network cinemas. The first part of the article is devoted to a survey of key determinants for Polish film academies' educational profiles, largely determined by the contents of the Core Curriculum. Subsequently, four case studies are conducted: the New Horizons of Film Education programme operating in the Network of Studio and Local Cinemas, Młodzieżowa Akademia Filmowa [Youth Film Academy] at Amok cinema in Gliwice, the Interdisciplinary Programme of Media Education KinoSzkoła [CinemaSchool] operating at independent cinemas and community culture centres in smaller towns and finally Akademia Filmowa Multikino [Multikino Film Academy]. In her conclusion, the author analyses these cases in the light of current European tendencies in film education, outlined in the document A Framework for Film Education.

Keywords: film literacy, film education 